\title{
CARACTERIZAÇÃO GENOTÍPICA DE CEPAS DE Salmonella Heidelberg DE ORIGEM
} AVÍCOLA

\section{Carolyne Ferreira Dumont ${ }^{1}$; Fernanda Aparecida Longato dos Santos ${ }^{2}$; Micaela Guidotti Takeuchi $^{3}$; Mariana Comassio Chueiri ${ }^{4}$; Newton Nascentes Galvão ${ }^{5}$; Daise Aparecida Rossi ${ }^{6}$; Roberta Torres de Melo ${ }^{7}$}

${ }^{1}$ Graduanda, Universidade Federal de Uberlândia (UFU), Uberlândia, Minas Gerais.

${ }^{2}$ Mestranda, Universidade Federal de Uberlândia (UFU), Uberlândia, Minas Gerais.

${ }^{3}$ Doutoranda, Universidade Federal de Uberlândia (UFU), Uberlândia, Minas Gerais.

${ }^{4}$ Graduanda, Universidade Federal de Uberlândia (UFU), Uberlândia, Minas Gerais.

${ }^{5}$ Doutor, Ministério da Agricultura, Pecuária e Abastecimento (MAPA), Brasília, Distrito Federal.

${ }^{6}$ Professora Doutora, Universidade Federal de Uberlândia (UFU), Uberlândia, Minas Gerais.

${ }^{7}$ Professora Doutora, Universidade Federal de Uberlândia (UFU), Uberlândia, Minas Gerais.

\section{DOI: 10.47094/IICNNESP.2021/22}

\begin{abstract}
RESUMO
A salmonelose é uma das principais causas de gastroenterite de origem alimentar no Brasil e o sorovar Salmonella Heidelberg $(\mathrm{SH})$ está envolvido em casos graves. O estudo objetivou avaliar aspectos genotípicos presentes em 20 cepas de $S H$ isoladas de carne de frango comercializados pela indústria brasileira para determinar o perfil de virulência via PCR convencional e a proximidade genética por PFGE. Todas as cepas apresentaram os genes ompC, invA, $\operatorname{sod} C, \operatorname{avrA}, \operatorname{lpf} A$, e $a g f A$, já o gene luxS foi detectado em $70 \%$ destas. A presença de diferentes genes de virulência revela que este sorovar pode representar uma ameaça à saúde pública. Houve elevada diversidade genética entre as cepas, que se agruparam em seis pulsotipos com características epidemiológicas e moleculares comuns. Concluise que as cepas apresentaram perfil multivirulento, distinguível pelo $\operatorname{lux} S$ e distanciamento genético compatível aos desafios relacionados à capacidade adaptativa do sorovar e às dificuldades de controle na indústria avícola.
\end{abstract}

PALAVRAS-CHAVE: PFGE. Virulência. Saúde pública.

ÁREA TEMÁTICA: Epidemiologia.

\section{INTRODUÇÃO}

A Salmonelose é uma das principais doenças de origem alimentar que afeta humanos no mundo todo. Geralmente é causada pelo consumo de carne de frango contaminada por sorovares zoonóticos, representando um grave problema a saúde pública. Salmonella Heidelberg $(\mathrm{SH})$ destaca- 
se entre os sorovares por sua prevalência em países da América do Norte, Europa e no Brasil (ANTUNES et al., 2016). O cenário torna-se pior diante da emergência de patógenos com perfis de virulência pertencentes a este sorovar.

São diversos os mecanismos moleculares envolvidos na virulência de $S H$. Entre estes genes, alguns são responsáveis por possibilitar o estabelecimento de doenças, como os genes de adesão (lpfA; agfA), invasão ( ompC; invA) e colonização ( $a v r A)$ (SUZUKI, 1994), enquanto outros permitem a manutenção da bactéria em ambientes adversos, como o gene (luxS) que permite a comunicação entre bactérias, a formação de biofilmes e a possibilidade de realizar trocas gênicas (BORGES et al., 2018).

O Brasil é um importante exportador na cadeia produtiva avícola e, apesar das medidas rígidas de controle sanitário, houve aumento na quantidade de cepas de $\mathrm{SH}$ isoladas nos últimos anos. Assim, monitoramentos são fundamentais para a implantação de medidas de controle mais eficientes. Dada a importância e a emergência de $\mathrm{SH}$, este estudo objetivou avaliar a proximidade genética e a virulência de linhagens de $S H$ de origem avícola para discutir o perigo que podem representar à saúde pública.

\section{METODOLOGIA}

Foram avaliadas 20 cepas de $\mathrm{SH}$, isoladas entre os anos de 2017 e 2018 em lotes de frangos de corte de oito unidades industriais (A, B, C, D, E, F, G e H) e cinco diferentes produtores (1, 2, 3, 4 e 5), com idades entre 11 e 46 dias. As cepas analisadas foram provenientes de $s w a b$ de arrasto do aviário (17), amostra fecal (1), amostra de ceco (1) e amostra de peito (1). A identificação bioquímica e sorotipagem foram realizadas pelo Laboratório de Enterobactérias da Fundação Oswaldo Cruz, no estado do Rio de Janeiro (IOC/FIOCRUZ, Rio de Janeiro, Brasil).

Para a detecção de genes de virulência, foi realizada a extração e purificação do DNA genômico usando o Wizard Genomic DNA Purification Kit ${ }^{\circledR}$ (Promega), seguidos da reação de PCR (10ng de DNA purificado), para detecção da presença dos genes $o m p C$ (biossíntese da proteína $\mathrm{C}$ da membrana externa), avrA (colonização da proteína efetora), sodC (eliminação de radicais livres), inv $A$ (invasão), sef $A$ (adesão de fímbrias), $a g f A$ (fímbrias e biofilme), $\operatorname{lpf} A$ (adesão de fímbrias) e $\operatorname{lux} S$ (mecanismo de detecção de quórum).

As reações de PCR foram conduzidas utilizando o kit GoTaq ${ }^{\circledR}$ Green Master Mix (Promega) com volume final de $25 \mu \mathrm{L}$. Posteriormente, foi realizada a amplificação em termociclador (Eppendorf): $94^{\circ} \mathrm{C}-5 \mathrm{~min}$; 35 ciclos de amplificação: $94^{\circ} \mathrm{C}-45 \mathrm{seg} ; 72^{\circ} \mathrm{C}$ - 90seg; $72^{\circ} \mathrm{C}-10 \mathrm{~min}$ e extensão final a $72^{\circ} \mathrm{C}-10 \mathrm{~min}$. Os produtos amplificados foram submetidos a eletroforese em gel de agarose a $1,5 \%$ (tampão de funcionamento TBE 0,5x Invitrogen) e o marcador de peso molecular 100bp (Invitrogen).

Para verificar a similaridade genética entre os isolados, foi utilizada a técnica Pulsed Field Gel Electrophoresis (PFGE) de acordo com o protocolo do PulseNet (CDC, 2017). Para essa técnica, as bactérias foram emblocadas em gel de agarose, seguida por digestão do DNA genômico a partir 
do uso da enzima Xbal (Invitrogen). Os fragmentos resultantes foram separados em gel de agarose 1\% (SeaKem Gold®), em tampão TBE 0,5X, no equipamento CHEF DRIII (Bio-Rad®, Califórnia, Estados Unidos) por $18 \mathrm{~h}$ ( $200 \mathrm{~V}$, ângulo de $120^{\circ}, 6 \mathrm{~V}$ gradiente/cm e temperatura do tampão de $14^{\circ} \mathrm{C}$ ). Posteriormente, os géis foram corados com brometo de etídio e as imagens reveladas em transiluminador (Loccus Biotechnology ${ }^{\circledR}$ ) e avaliadas com o programa BioNumerics. A análise estatística foi realizada com o software GraphPad Prism, versão 8.0 (GraphPad Software, Estados Unidos), considerando nível de confiança de 95\% na análise das variáveis.

\section{RESULTADOS E DISCUSSÕES}

Os resultados evidenciaram a presença dos genes $\operatorname{omp} C, \operatorname{inv} A, \operatorname{sod} C$, avrA, $\operatorname{lpf} A$, e agfA em todas as estirpes e o gene $\operatorname{luxS}$ em 70\%. A presença dos genes ompC e invA era esperada pois ambos são utilizados para caracterizar o gênero e a capacidade de invadir os tecidos hospedeiros, respectivamente. $\mathrm{O}$ gene $\operatorname{sefA}$ não foi identificado nas cepas e está associado com o processo de adesão restrito aos serovares do grupo D, Enteritidis, Dublin, Moscovo e serotipos Blegdon (AMINI et al., 2010). Entretanto, sua presença foi investigada devido à possibilidade de realizar recombinação genética, por meio de transferência horizontal de genes, que pode ser mais evidente quando os genes sef $A B C D$ apresentam $\mathrm{G}+\mathrm{C}$ com aproximadamente $35,2 \%$.

Indicando um risco potencial após a infecção, os genes agfA e $\operatorname{lpf} A$, codificam proteínas associadas à fixação celular a superfícies abióticas e formação de biofilme para posterior colonização intestinal e expressão de virulência (YOO et al., 2013). O gene avrA altamente conservado tem grande importância para a saúde pública devido sua capacidade de promover o escape do sistema imune do hospedeiro que se verifica por meio da indução de apoptose celular, limitando a resposta inflamatória à infecção (LABRIOLA; ZHOU; NAGAR, 2018). Concomitantemente, codifica-se proteínas efetoras essenciais para a infecção e proliferação bacteriana.

Observa-se na Figura 1, que parte das estirpes (30\% - 6/20) apresentaram ausência do gene luxS (-luxS) que podem demonstrar formação de estruturas sésseis pouco estáveis ou com baixa carga bacteriana comparativamente a estirpes com a presença do gene (+luxS). A proteína luxS está correlacionada com o controle e a sinalização do mecanismo de quórum sensing, que permitem a organização da população bacteriana e a estabilidade/maturidade da estrutura dos biofilmes (PARVEEN; CORNELL, 2011). 
Figura 1: Dendrograma comparativo de 20 estirpes Salmonella Heidelberg indicando a presença ou ausência do gene luxS. Utilizou-se o coeficiente de semelhança de dados com tolerância de 1,5\% e o método UPGMA

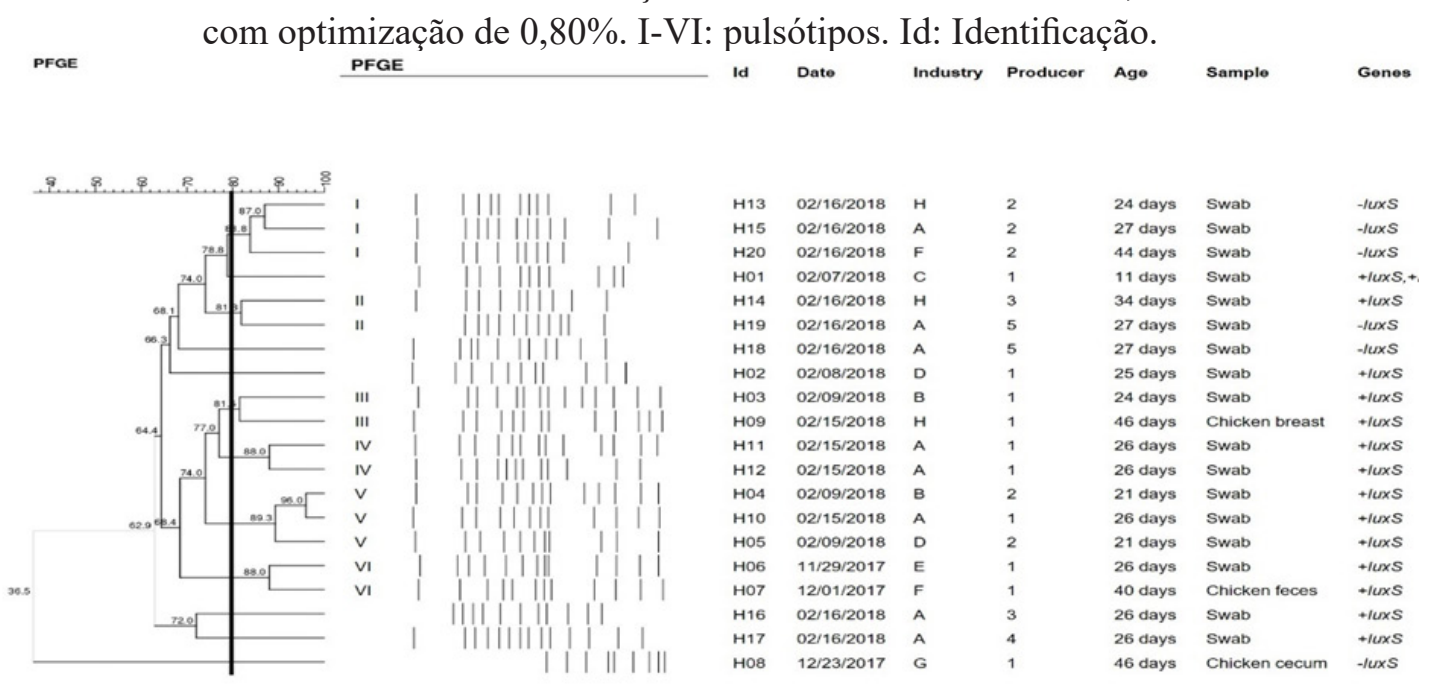

Fonte: própria autoria

Para avaliação das semelhanças genotípicas através da tipagem por PFGE $(>80 \%$ de similaridade), estruturou-se o dendograma baseado nas características genotípicas, no local de isolamento e na data da coleta (Figura 1). A análise de semelhança apresentou seis pulsotipos (I-VI), reunidos com duas ou três estirpes, demonstrando uma origem ou produtor comum cujo genótipo foi disseminado para unidades industriais diferentes. Exceção foi observada para o pulsotipo IV, que continha características epidemiológicas e moleculares comuns. Neste caso, a manutenção local do microrganismo em diferentes amostras pode ser ligada à contaminação cruzada.

As estirpes isoladas de diferentes anos não foram agrupadas no mesmo pulsotipo e o mesmo padrão aplicou-se para o produtor (exceto para os pulsotipo II e V) e para o painel genético (exceto para os pulsótipos III e IV).

\section{CONCLUSÃO}

O estudo demonstrou ampla distribuição de perfis multivirulentos de $\mathrm{SH}$, distinguíveis somente ao potencial de formação de biofilmes. A alta heterogeneidade filogenética dos sorovares em curta variação temporal demonstra seu potencial recombinante e os desafios constantes para o controle de $\mathrm{SH}$ na produção avícola.

\section{PRINCIPAIS REFERÊNCIAS}

ANTUNES, P. ANTUNES, P. et al. Salmonellosis: the role of poultry meat. (s.l.): Clinical Microbiology and Infection, 2016.

AMINI, K. et al. Molecular detection of invA and spv virulence genes in Salmonella enteritidis isolated from human and animals in Iran. (s.l.): African Journal of Microbiology Research, 2010. 
BORGES, K. A. et al. Biofilm formation capacity of Salmonella serotypes at different temperature conditions. Rio de Janeiro: Pesquisa Veterinária Brasileira, 2018.

CDC. Standard Operating Procedure for PulseNet PFGE of Escherichia coli O157: H7, Escherichia coli non-O157 (STEC), Salmonella serotypes, Shigella sonnei and Shigella flexneri. v. 157, p. 1-16, 2017.

LABRIOLA, J. M.; ZHOU, Y.; NAGAR, B. Structural Analysis of the Bacterial Effector AvrA Identifies a Critical Helix Involved in Substrate Recognition. Washington: Biochemistry, 2018.

PARVEEN, N.; CORNELL, K. A. Methylthioadenosine/S-adenosylhomocysteine nucleosidase, a critical enzyme for bacterial metabolism. (s.l.): Molecular Microbiology, 2011

SUZUKI, S. Pathogenicity of Salmonella enteritidis in poultry. (s.l.): International Journal of Food Microbiology, 1994.

YOO, A. Y. et al. Role of sigma factor $\mathbf{E}$ in regulation of Salmonella Agf expression. (s.l.): Biochemical and Biophysical Research Communications, 2013. 